\title{
An Empirical Study on Factors that Affect University Teacher Job Satisfaction In Beijing
}

\author{
Luo Xing ${ }^{1, a^{*}}$ \\ ${ }^{1}$ Beijing International Studies University,Beijing,China \\ aluoxing@bisu.edu.cn
}

Keywords: University teacher, Beijing , Job Satisfaction, Factors.

\begin{abstract}
This study explores factors that affect university teacher job satisfaction in Beijing. A quantitative approach was applied among 123 teachers of Beijing International Studies University. The result indicate that there are 3 main factors that affect teacher job satisfaction in Beijing, including working condition, living condition, and mental condition, among which working condition provides most Influence. The study suggests that for universities in Beijing which would made effort to improve teacher job satisfaction, it would be wise to improve awarding system, provide rich academic resources and built a fair system, and unwise to try to improve teachers' social relationship or to reduce teachers' financial stress.
\end{abstract}

\section{Introduction}

Construction and improvement of teach team is one of the core impetus for development of universities, which involves methods to keep valuable teachers and to motivate teachers' work. Katharina Michaelowa(2007) found out that there is a positive impact of teacher job satisfaction on education quality[1]. Which means trying to improve teacher satisfaction could be a solution.

Fay and David found out that identification of factors that could be affected through administrative intervention, the quality of school working condition, respondents' relationships with other teachers, School prestige and parental encouragement are significant predictors for public school teachers[2]. Dinham and Scott(1998) named eight factor including school leadership, climate, decision making; merit promotion and local hiring; school infrastructure; school reputation; status and image of teachers; student achievement; workload and the impact of change; and professional[3]. self-growth Simin and Nova found out that there is a significant positive relationship between school organizational climate and teachers' job satisfaction[4].

However, Shujie Liu and Anthony(2014) found out that some job-satisfaction factors were specific to China[5]. In China, studies on teacher satisfaction commonly focus on job nature, payback, environment, management and organization development. FengBolin(1996) believes that 5 factors affect teacher job satisfaction are self accomplish, work load, salary, relationship with leaders, relationship with colleagues[6]. While Yuan Ling(2006) believes those factors include work nature, working environment, salary, further education and relationship[7]. Liu Gang(2006), on the other hand, believes that sense of challenging, fair payback, supporting working environment, harmonious relationship and match of personality could produce influence on teacher job satisfaction[8].Chen Junjun(2010) found out that The sub-factors of leadership, professional opportunities, working condition, and income had significant relationships with teachers' future career planning[9].

\section{Method}

This study explores factors that affect university teacher satisfaction, and determines effective ways to improve which.

2.1 Research instrument. Based on literatures and interviews with teacher management staff and teachers, an anonymous questionnaire was designed. The questionnaire includes 22 questions, in which the 5 point Likert-type scale was used. From 1 to 5 points means most unsatisfied to most satisfied. 
2.2 Sample. According to Gorsuch (1983), in factor analysis study, the question/sample ratio would be better below 1/5, and the sample should cover more than 100 individuals. A sample of 178 teachers of Beijing International studies university was approached, which contains teachers of different subjects, age, teacher seniority and titles. 123 questionnaires were valid after filtered and the question/sample ratio is 1/5.6, which means the study would acquire Gorsuch's demands.

2.3 Analysis. Data were analysed in SPSS 23,exploratory factor analysis with principle components analysis and oblique rotation was applied to found out main factors that affect teacher satisfaction. The Cronbach coefficient alpha $(\alpha)$ was tested by scale reliability analysis, which is .94 in this study, means the study could be trusted. Correlation analysis was applied to determine whether the data were suitable for factor analysis, the Kaiser-Meyer-Olkin (KMO) measure of sampling adequacy is .919 , and the significant probability of Barlett's test of sphericity $p=.000<.01$, which means the data were highly suitable for factor analysis.

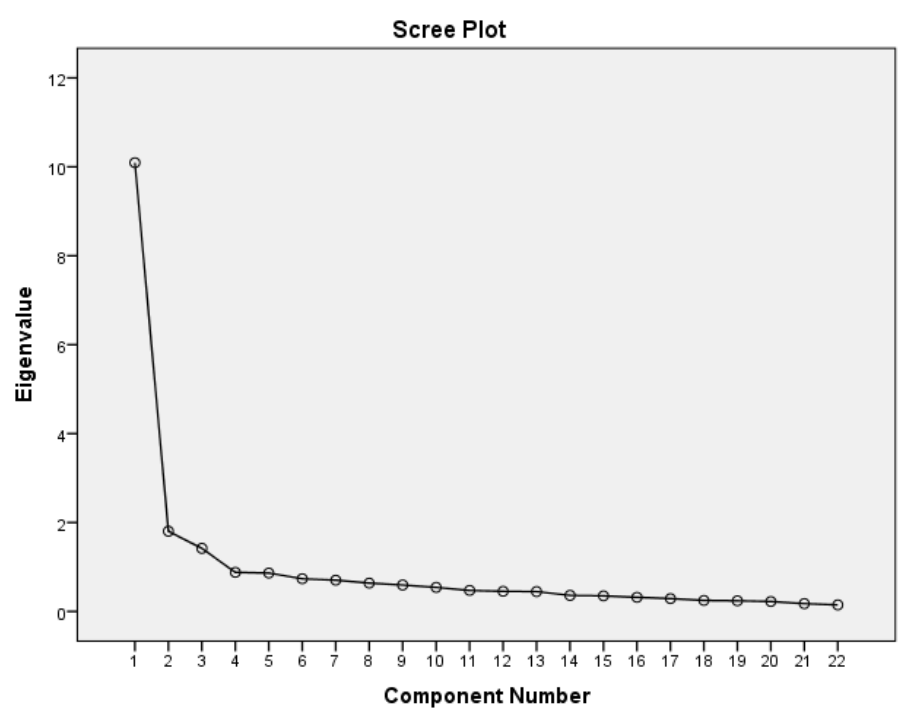

Fig. 1. Scree plot

Tab. 1. Factor analysis

\begin{tabular}{|c|c|c|c|c|c|c|c|c|}
\hline \multirow{2}{*}{ Factors } & \multicolumn{2}{|c|}{ Initial Eigenvalues } & \multirow{2}{*}{ Variables } & \multicolumn{3}{|c|}{$\begin{array}{c}\text { Rotated Component } \\
\text { Matrix } \\
\end{array}$} & \multirow{2}{*}{ Extraction } & \multirow{2}{*}{$\begin{array}{l}\% \text { of } \\
\text { Weigh }\end{array}$} \\
\hline & Total & $\begin{array}{c}\% \text { of } \\
\text { Variance }\end{array}$ & & 1 & 2 & 3 & & \\
\hline \multirow{12}{*}{$\begin{array}{l}\text { Working } \\
\text { Condition }\end{array}$} & \multirow{12}{*}{10.093} & \multirow{12}{*}{45.88} & Teaching Awarding & .841 & .151 & .058 & .734 & 5.33 \\
\hline & & & Research Awarding & .823 & .150 & .015 & .701 & 5.17 \\
\hline & & & Service Awarding & .749 & .299 & .103 & 660 & 5.21 \\
\hline & & & Academic resources & .729 & .273 & .196 & .645 & 5.15 \\
\hline & & & Promotion System & .709 & .218 & .097 & .559 & 4.77 \\
\hline & & & $\begin{array}{l}\text { Participation in } \\
\text { Decision-making }\end{array}$ & $\underline{.684}$ & .119 & .062 & .485 & 4.34 \\
\hline & & & Income Distribute & .679 & .333 & .050 & .574 & 4.82 \\
\hline & & & Fund Projects & .676 & .282 & .169 & .564 & 4.82 \\
\hline & & & Further Education & .651 & .232 & .031 & .478 & 4.39 \\
\hline & & & Career Prospect & .619 & .439 & .236 & .631 & 5.04 \\
\hline & & & Working Facility & .500 & .411 & .244 & .478 & 4.38 \\
\hline & & & Leader's attention & .482 & .331 & .468 & .561 & 4.67 \\
\hline \multirow{4}{*}{$\begin{array}{l}\text { Living } \\
\text { Condition }\end{array}$} & \multirow{4}{*}{1.805} & \multirow{4}{*}{8.21} & Finance Stress & .018 & .847 & -.109 & .729 & 3.85 \\
\hline & & & Living Quality & .165 & .815 & .036 & .693 & 4.54 \\
\hline & & & Children's Education & .421 & .681 & .002 & .642 & 4.92 \\
\hline & & & Social Security & .446 & .671 & .070 & .653 & 5.08 \\
\hline
\end{tabular}




\begin{tabular}{|c|c|c|c|c|c|c|c|c|}
\hline & & & Physical healthy & .363 & .637 & .216 & .585 & 4.82 \\
\hline & & & Welfare & .480 & .592 & .238 & .638 & 5.12 \\
\hline & & & Work Load & .462 & .531 & .066 & .500 & 4.48 \\
\hline \multirow{3}{*}{$\begin{array}{l}\text { Mental } \\
\text { Condition }\end{array}$} & \multirow{3}{*}{1.419} & \multirow{3}{*}{6.45} & Collegiality & .116 & $\overline{.137}$ & .779 & .640 & 3.10 \\
\hline & & & $\begin{array}{l}\text { Teacher-student } \\
\text { relationship }\end{array}$ & -.052 & -.176 & .722 & .554 & 1.18 \\
\hline & & & Accomplishment & .517 & .268 & .521 & .611 & 4.80 \\
\hline
\end{tabular}

\section{Results}

3.1 Teacher job satisfaction. The overall mean score for teacher job satisfaction is 2.89 , which is below the score of 3, means samples are commonly not satisfied of their jobs. 57 samples have a scored over 3 , which account for 46.3 percent of all samples, 10 samples scored over 3.75 , account for 8.1 percent.

3.2 Factor analysis[11]. As shown in Fig. 1, sree test was applied. The slope of the line tend to be gentle from the 4 th factor, indicates that there are no more special factors to be extracted. As shown in Tab. 1, eigenvalues-one rule test was applied, the existence of 3 factors could explain 60.54 percent of the variance of 22 variables, initial characteristic value of 3 factors are all above 1 , the commonality of all variables are all above .4. Those test results come to an conclusion that 3 main factors could be conducted from 22variables.

3.3 Factor meanings. By conclusion of the meanings of each variables, the meaning of 3 main factors could be identified as Working Condition, Living Condition and mental condition, each factor could provide different influence on teacher job satisfaction.

Working condition provides a highest variance of 45.88 percent, which indicate that to provide a better working condition would be most efficient way to improve university teacher job satisfaction. It is because that better awarding system would inspire teachers' creation and motivate their job honor. Better working facilities would provide researching condition and encourage teachers to stay in working area. Fair and reasonable system of awarding, income distributing and promoting would motivate teachers to improve their professional skills and to produce and serve more to universities. Abundant academic resources and rich research fundings could provide a better researching environment. Further education with high quality would improve teachers' professional skills and broaden their career future. Participation in decision-making would provide teachers senses of ownership of the university. Working condition, including hardware and software system, is rucial to maintain stability of teach team, and to motivate teachers' working enthusiasm.

Living condition has a less variance of 8.21 percent, which indicates that it has some influence on job satisfaction. Teachers could chose to quit or switch jobs because of poorly living state, if they suffer serious stress or sense insecurity of life insurance. The financial problems and children's education problems would occupy their time and energy which they should spent on working.

Mental environment has a least variance of 6.45 percent. The human environments are commonly harmony in Beijing universities, and teaching is a job with great accomplishment. Therefore, quite high scores are gained in all 3 questions, among which mean scores over 4 have been acquired in collegiality and teacher-student relationship. It would be difficult for universities to improve teachers mental environment.

3.4 Variable weight. By standardizing the sum of the products of initial characteristic value of factors and factor score coefficient, weight of all questions could be determined and to be sorted. The teaching awarding, service awarding and researching awarding have strongest weight and teacher-student relationship, collegiality and financial stress have weakest weight on job satisfaction. The teacher-student relationship and collegiality have quite high mean scores already and could not easily uprise, and living in Beijing would cause very high stress, which could not be easily released by universities. 


\section{Summary}

Improving teacher job satisfaction is an effective way to inspire their work. By analysing teacher job satisfaction of Beijing International Studies University, 3 main factors were determined as working condition, living condition and mental condition, among which working condition provides most influence on job satisfaction.

Therefore, it is wise for universities to improve working condition to gain a higher satisfaction, which includes providing better working facilities, builting reasonable policy systems and providing rich further education and academic resources. Establishing a fair awarding system could inspire teachers the most. On the contrary, it is not efficient to make effort to improve social relationships and reduce teachers' financial stress.

\section{References}

[1] Michaelowa K, Wittmann E, The Cost, satisfaction, and achievement of primary education: evidence from francophone sub-saharan Africa, Journal of Developing Areas, vol.41(1), pp. 51-78, 2007.

[2] Rodgers-Jenkinson F, Chapman D W, Job satisfaction of Jamaican elementary school teachers, International Review of Education, vol.36(3), pp. 299-313, 1990.

[3] Dinham S, Scott C, A three domain model of teacher and school executive career satisfaction, Journal of Educational Administration, vol.36(4), pp. 362-378, 1998.

[4] Ghavifekr S, Pillai N S, The relationship between school's organizational climate and teacher's job satisfaction: Malaysian experience, Asia Pacific Education Review, vol.17(1), pp. 1-20, 2016.

[5] Liu S, Onwuegbuzie A J, Teachers' motivation for entering the teaching profession and their job satisfaction: a cross-cultural comparison of China and other countries, Learning Environments Research, vol.17(1), pp. 75-94, 2014.

[6] Feng Bolin, Study on Teacher job satisfaction and it's factors, Education Study, vol.(2), pp. 42-49, 1996

[7] Yuan Ling, Xie Chi, XIE Fa-sheng, An Investigation and Analysis of the Teachers' Job Satisfaction in Higher Education, Journal of Educational Science of Hunan Normal University, vol.5(3), pp. 103-106, 2006.

[8] Liu Gang, The Analysis on University Teachers' Job Satisfaction, Journal of Educational Science of Hunan Normal University, vol.20(4), pp. 68-73, 2006.

[9] Chen J, Chinese middle school teacher job satisfaction and its relationships with teacher moving, Asia Pacific Education Review, vol.11(3), pp. 263-272, 2010.

[10]Gorsuch, Richard L, Factor Analysis, Hillsdale, NJ: Erlbaum, 1983.

[11]Costello A B, Osborne J W, Best Practices in Exploratory Factor Analysis: Four Recommendations for Getting the Most From Your Analysis, Practical Assessment, vol.10(7), pp. 1-9, 2005. 